\section{A case of mixed connective tissue disease combined with sarcoidosis}

Mixed connective tissue disease (MCTD) is an overlap syndrome accompanied by high levels of anti-ribonucleoprotein (RNP) antibodies and RNase-sensitive anti-ENA antibodies. ${ }^{12}$ Sarcoidosis, on the other hand, is a systemic granulomatous disease with reduced cellular immunity and increased humoral immunity. ${ }^{3}$

We report a case of MCTD associated with sarcoidosis. The patient was a 61 year old Japanese woman complaining of exertional dyspnoea and Raynaud's phenomenon. A chest $x$ ray showed fine reticular/granular shadows in both lower lung fields with slight swelling of the bihilar lymph nodes. A superficial lymph node was palpable in the left neck $(10 \mathrm{~mm}$ diameter $)$ and the right supraclavicular fossa (2-3 mm diameter). Heart sounds were regular, no murmurs were audible. Fine crackles were heard on auscultation in both lower lung fields. There was scleroderma of the fingertips on both hands as well as a swollen right fourth finger. Mild anaemia (RBC $3.22 \times 10^{6} / \mathrm{mm}^{3}, \mathrm{Hb} 10.7 \mathrm{~g} / \mathrm{dl}$, Ht $31.7 \%)$ and mild leukopenia $\left(3,600 / \mathrm{mm}^{3}\right)$ were observed. Arterial blood gas analysis revealed $\mathrm{pH} 7.434, \mathrm{PaO}_{2} 72.7 \mathrm{~mm} \mathrm{Hg}$, $\mathrm{PaCO}_{2} 37.3 \mathrm{~mm} \mathrm{Hg}, \mathrm{HCO}_{3}^{-} 24.8 \mathrm{mEq} /$, $\mathrm{BE}+0.8 \mathrm{mEq} / \mathrm{l}$, and oxygen saturation $94.8 \%$, indicating reduced pulmonary diffusing capacity. Pulmonary function test also revealed decreased diffusing capacity ( $\mathrm{DL}_{\mathrm{CO}} 67 \cdot 4 \%$ ), whilst neither constrictive nor obstructive change was noticed. The erythrocyte sedimentation rate (ESR) was $118 \mathrm{~mm} /$ hour. $\mathrm{CRP}$ was negative. Acetylcholine esterase level was at the upper limit of normal range (19.4 IU/l), lysozyme was slightly elevated $(18.0 \mathrm{mg} / \mathrm{ml})$, antinuclear antibodies (++, speckled pattern), RNase-sensitive antiENA antibodies $(\times 20480)$, anti-RNP antibodies $(\times 16)$ and anti-DNA antibodies $(\times 160)$ were positive, but anti-Sm, anti-Scl, anti-Jol, and anti-double-stranded DNA antibodies (IgG), and the LE test were negative. The rheumatoid factor level, immune complexes and the $\mathrm{CH}_{50}$ were within normal range.

A CT scan of the thorax showed slight enlargement of the bihilar lymph nodes and infiltration mainly in the lower lung fields (fig $\mathrm{A}, \mathrm{B}$ ), and a $\mathrm{Ga}$ scintiscan revealed diffuse isotope accumulation in both lung fields. She had polyarthralgia in her hand and knee joints and was therefore diagnosed as having MCTD. A transbronchial lung biopsy revealed granulomas associated with epitheloid cells within the pulmonary tissue (fig $\mathrm{C}$ ). Increase of total cell count $\left(1.2 \times 10^{5} / \mathrm{ml}\right)$ with considerable lymphocytosis $(68.6 \%)$ was observed in bronchoalveolar lavage fluid, which was compatible with sarcoidosis. Sputum and gastric juice were negative for tubercle bacilli. The tuberculin reaction was negative. A diagnosis of associated sarcoidosis was made.

On day 51 the onset of intercurrent iritis was noted. An associated heart lesion was suspected because of multifocal paroxysmal ventricular contractions. Oral prednisolone (30 $\mathrm{mg} /$ day) was administered for three weeks and the dose was decreased. All her signs and symptoms improved. The arterial blood gas data were normal, lysozyme levels and all the autoantibody titres had decreased, and the infiltration shadows on the chest $x$ ray and CT scan gradually improved.

Collagen disease-type symptoms sometimes occur in sarcoidosis, while noncaseating epitheloid cell granulomas are sometimes observed in the spleen and other organs in systemic lupus erythematosus $(\mathrm{SLE},)^{4}$ and in aponeuroses in progressive systemic sclerosis (PSS). ${ }^{5}$ The concomitant progression of MCTD and sarcoidosis and their remission by steroid treatment in our patient suggest that the two diseases are immunologically related. The increased humoral immunity and decreased cellular immunity seen in sarcoidosis is reported to closely resemble SLE and the autoimmune disease model in New Zealand mice. ${ }^{6}$ To date only one case of an association between MCTD and sarcoidosis has been reported. ${ }^{7}$

There have been occasional reports of sarcoidosis associated with SLE, ${ }^{6} \mathrm{PSS},{ }^{6} \mathrm{RA}^{8}$ and primary biliary cirrhosis. ${ }^{9}$

MASATO MIZUMOTO YUKIHIKO ADACHI JUNICHI CHIHARA TAKASHI MATSUMOTO TAKASHRO YAMAMOTO TAKAHRO YAMAMOTO SHIGENORI NAKAJIMA
TOSHIO YAMAMOTO

The 2nd and 4th Departments of Internal Medicine Kinki University School of Medicine Osakasayama, 589 Japan

1 Sharp G C, Irvin W S, Tan E M, Gould R G, Holman H R. Mixed connective tissue Holman $H$ R. Mixed connective tissue disease an apparently distinct rheumatic disease syndrome associated with a specific antibody to an extractable nuclear
(ENA). Am f Med 1972; 52: 148-59.

2 Tohjo T. Diagnotic criteria of mixed connective tissue disease and overlapping syndrome Naika 1990; 65: 1283-5.

3 Brown J K. Pulmonary sarcoidosis. Semin Resp Med 1991; 12: 215-28.

4 Cruickshank B. The basic pattern of tissue damage and pathology of systemic lupus erythematosus. In: Dubois E L, ed. Lupus erythematosus, 2nd ed. Los Angeles: Univererythematosus, 2nd ed. Los Angeles: Univer-
sity Southern California Press, 1976: 12-64.

5 Shulman L E, Kurban A K. Tendon friction rubs in progressive systemic sclerosis (scleroderma). Trans Assoc Am Physicians 1961; 74: 378-88.

6 Wiesenhutter C W, Sharma O P. Is sarcoidosis an autoimmune disease? Report of four cases and review of the literature. Semin Arthr Rheumat 1979; 9: 124-44.

7 Igarashi A, Ohtsuka F, Ishibashi Y, Nakao A. A case of mixed connective tissue disease accompanied with sarcoidosis. Hifurinsho 1987; 29: 434-5.

8 Fallahi S, Collins R D, Miller R K, Halla J T. Coexistence of rheumatoid arthritis and sarcoidosis: difficulties encountered in the differential diagnosis of common manifestations. F Rheumatol 1984; 11: 526-9.

9 Ishida S, Komatsu M, Nakajima $K$, Goto $M$, Watanabe $\mathrm{H}$, Masamune $\mathrm{O}$. A case of primary biliary cirrhosis associated with sarcoidosis. fpn f Gastroenterol 1991; 88: 1603-7.

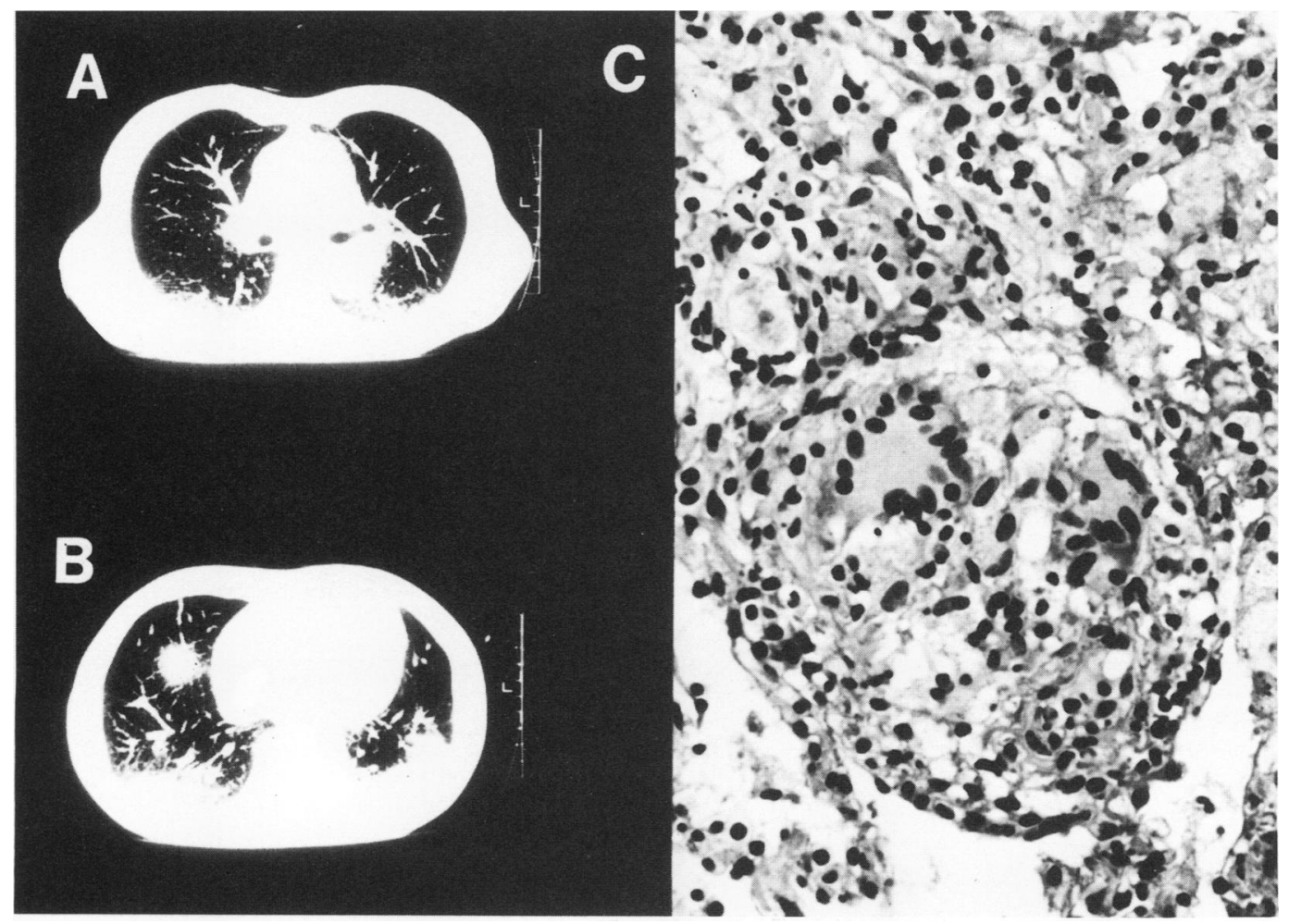

Pulmonary $C T$ scans $(A$ and $B)$ and histology of the lung tissue obtained by a transbronchial biopsy $(C)$. Enlargement of bihilar lymph nodes $(A)$ and infiltration mainly in the lower lung fields $(B)$ were observed on $C T$ scans. Histology $(C)$ showed epitheloid cells and Langhans-type giant cells in granulomas ( $H \mathcal{E}$ E; original magnification $\times 200)$. 